Article

\title{
Decision-Making Behavior and Risk Perception of Chinese Female Wildlife Tourists
}

\author{
Li Cong ${ }^{1, *}$, Qiqi Wang ${ }^{1,2}$, Geoffrey Wall ${ }^{3, *}$ (i) and Yijing Su ${ }^{1}$ \\ 1 School of Landscape Architecture, Room 1311, Xueyan Building, Beijing Forestry University, \\ Beijing 100083, China; wangqiqiwqq19@126.com (Q.W.); 18811722183@163.com (Y.S.) \\ 2 School of Social Sciences, Hong Kong Baptist University, Waterloo Road, Kowloon Tong, \\ Hong Kong 999077, China \\ 3 Department of Geography and Environmental Management, University of Waterloo, \\ Waterloo, ON N2L3G1, Canada \\ * Correspondence: Lisacong@bjfu.edu.cn (L.C.); wall_geoffrey@hotmail.com (G.W.)
}

Citation: Cong, L.; Wang, Q.; Wall, G.; Su, Y. Decision-Making Behavior and Risk Perception of Chinese Female Wildlife Tourists. Sustainability 2021, 13, 10301. https://doi.org/10.3390/su131810301

Academic Editor: Michael Tarrant

Received: 12 August 2021

Accepted: 7 September 2021

Published: 15 September 2021

Publisher's Note: MDPI stays neutral with regard to jurisdictional claims in published maps and institutional affiliations.

Copyright: (c) 2021 by the authors. Licensee MDPI, Basel, Switzerland. This article is an open access article distributed under the terms and conditions of the Creative Commons Attribution (CC BY) license (https:// creativecommons.org/licenses/by/ $4.0 /)$.
Abstract: Prior to the global pandemic, wildlife tourism was increasing rapidly globally but was in the early stages of development in China, where it faces great challenges and opportunities. Women comprise a substantial proportion of the market but their decision-making behavior and their perceptions of risk in wildlife tourism have not yet been explored. This paper explores relationships between risk perception and decision-making in tourism. A survey of female tourists was undertaken at non-captive and semi-captive wildlife sites in western China, as well as through internet website posting, resulting in 415 completed questionnaires. Quantitative methods were used to examine four sequential stages of decision-making in wildlife tourism: destination selection, trip itinerary, travel mode and security assurance, and entertainment consumption. Three dimensions of risk perception in wildlife tourism were identified: physical safety, personal comfort, and quality of experience. Decision-making behavior and risk perceptions are related. Perceived risks greatly impact tourists' travel mode and security assurance decisions. The higher the perceived risk, the greater the likelihood of female tourists participating in decisions on destination selection, travel methods and other entertainment activities undertaken on their wildlife tourism trips. Concerns regarding personal comfort positively influence destination selection, the trip itinerary, and recreation and consumption decisions. Assurance of acquiring a quality experience influences entertainment consumption decisions. The study contributes to the understanding of risk, decision-making behavior and gender research, and confirms the practical importance of safety considerations at wildlife destinations.

Keywords: female tourism; wildlife tourism; decision-making; risk perception; China

\section{Introduction}

Wildlife tourism has gained increasing research attention globally, including studies of Chinese wildlife tourists [1]. The development of wildlife tourism in China is facing great opportunities and challenges. China faces pressures from scarce resources, a large population and rapidly growing tourism, and semi-captive wildlife tourism destinations, such as wildlife safari parks and aquariums, have become preferred places for many wildlife lovers, parent-child families and female tourists in China [2]. Traditional views regarding wildlife pose problems for the resolution of conflicts between wildlife conservation and tourism development. Improper behavior is resulting in serious environmental problems, such as a sharp decline in biodiversity, environmental degradation and even severe public health crises. The coronavirus $(2019-\mathrm{nCoV})$ crisis centered on Wuhan has pushed the relationships between humans and wildlife into prominence [3]. Thus, it is important to explore the characteristics of Chinese wildlife tourists and their behavior [4]. Tourists' attitudes and behavior regarding wildlife are vital aspects of the sustainable development of wildlife tourism. 
At the same time, increased attention is being given to the roles of women as travel consumers [5] with profound implications for tourism development [6,7]. However, there are differences between the Asian and other markets [8]. A recent incident caused a sensation in China regarding women and wildlife tourism. On 23 July 2016, Ms. Zhao and her family visited Beijing Wildlife Park on a self-drive tour. She exited the car and was then dragged away by a tiger. On seeing this, Ms. Zhao's mother immediately got out of the car and was killed by another tiger. Ms. Zhao was seriously injured and was rushed to hospital. The incident resulted in heated public discussion about the risk perception and decision-making behavior of female tourists in wildlife settings in China.

In the fierce competition for source markets, the needs and desires of women have been receiving increasing attention [9,10]. Yang, Khoo-Lattimore, and Arcodia (2017) [11] stressed the importance of understanding gender differences in tourism in varying circumstances. As long ago as 1982, Monk and Hanson wrote "Do not exclude half of humanity in human geography", marking feminism as one of three philosophical movements in human geography [12]. Gender differences in tourism had been identified prior to this [13]. Now, there is a substantial body of work on tourists' behavior, decision-making, safety perceptions, shopping, constraints and appropriate research methods [14-18]. Substantial differences in motivation and behavioral preferences have been found in association with the gender of tourists [18]. Research on Chinese women has focused upon marketing and consumer behavior related to the tourist gaze [19], and their solo travel and related risk-taking experiences $[16,18]$. As Chinese female education levels and economic independence continue to increase, female decision-making powers in many aspects of life, including travel and entertainment, are increasing [20]. However, female roles in trip decision-making and risk perception are under-explored and have yet to be considered in wildlife tourism.

Having addressed aspects of wildlife tourism in previous research, the above incident at the Beijing wildlife park prompted further research into the risk perception and decisionmaking behavior of female wildlife tourists. Accordingly, the following objectives will be explored in this paper:

- $\quad$ To describe characteristics of female tourists participating in wildlife tourism;

- To examine the risk perceptions of Chinese female wildlife tourists;

- To explore the involvement of Chinese female tourists in tourism decision-making and the demographic factors impacting them;

- To validate the relationship between risk perception and participation in tourism decision-making.

\section{Literature Review, Research Hypotheses, and Model}

\subsection{Literature Review}

\subsubsection{Wildlife Tourism}

Research on wildlife tourism gained increased attention following the publication of Shackley's (1996) [21] book Wildlife Tourism. It covered a variety of topics such as products and suppliers [22], theoretical frameworks [23], impacts on wildlife [24], stakeholders [25], and destination management [26]. Sustainable development is an important topic for wildlife tourism [27]. The attributes of wildlife tourists have gained considerable attention, including, their spatio-temporal behavior [28], their experiences [4], satisfaction [29], educational benefits [30], and the factors that influence these, including demographic characteristics, personality, risk perception, motivation, environmental attitudes [30], and habitat type [31]. The theory of planned behavior, and approaches to environmental attitudes, such as involvement theory and actor-network theory [32] have been used to guide studies. Curtin (2009) [33] advised of the need to avoid anthropocentrism. Serious wildlife tourists have been differentiated from casual wildlife tourists [34]. Most studies have been undertaken in Australia, United States, United Kingdom, New Zealand and Canada and Africa, as well as elsewhere [35,36], but there has been a lack of attention to Asian countries such as China [37]. Chinese wildlife tourists' attitudes to wildlife tourism 
attractions have been found to have similarities to those found elsewhere, but there are differences in management applications [1]. There is a lack of research on female wildlife tourists and on the decision-making behavior of women in wildlife tourism. Although the gender of respondents is commonly reported, research results are rarely analyzed or presented from the perspective of women, which is a viewpoint that has received little attention and currently lacks in-depth discussion.

\subsubsection{Female Decision-Making Behavior}

Early research on female tourists' decision-making behavior is more systematic. As early as 1978, Jenkins began to pay attention to the role of women in family tourism decision-making. Research on female tourists' decision-making mainly focuses on three aspects: the extent of involvement of women in decision-making [13], the specific content of decision-making [25,38] and the factors influencing decision-making [39-41].

Research on whether or not women participate in decision-making in tourism and the degree of decision-making is of growing interest. Female decision-making behavior in the various stages and aspects of the tourism process has attracted considerable attention, including preparation activities, financial aspects and decisions made at the destination [20]. Wills (2002) [42] identified three phases: demand generation, information gathering and final purchase decisions. The content of decisions includes: destination selection, determining travel time and duration, information collection and travel service selection, budget design, preparing luggage, transportation arrangements and accommodation selection, event selection, shopping [41], and other tasks in the entire set of travel decisions [38]. Zalatan (1996) [43] highlighted travel departure and return times, purchase of insurance, attractions and destination activities.

Regarding the specific content of women's decision-making in tourism, many aspects need to be considered, such as time and distance considerations, leisure time, consumption level, traffic conditions, tourism destination popularity, service conditions, and safety issues [25,39]. Decisions were divided into three types according to the different roles of husband and wife in the decision-making process, with feminists emphasizing the roles of women in tourism decision-making [13]. Before the 1950s, most family travel decisions were made by the husband but, along with socio-economic development and greater female involvement in the economy, female participation in tourism decision-making has increased. Such involvement is influenced by a variety of factors which can be divided into two main groups: the external environment in which the tourist is located and the attributes of the tourist, such as personal psychological and socio-economic factors [44], including age. Tourism decisions by females are also affected by family structure, resource contributions, cultural values, and risk perceptions [45]. Other variables are of importance in other relevant tourism and travel decision-making models, such are: cost, travel time, flexibility, privacy, air quality impact, $\mathrm{CO}_{2}$ emissions impact, reliability, availability and reputation [46]. Although research on female tourism decision-making has become more abundant as tourism consumption by women has escalated, consumer preferences and consumption methods have undergone tremendous changes, so that it is now increasingly important to differentiate among different types of decisions and decision-makers.

\subsubsection{Tourism Risk}

Tourism risk is defined as the risk perceived and experienced by tourists during their purchase and consumption during travel [47]. Visitors' risk perceptions influence their on-site behavior and their intention to return to a destination and to recommend it to others $[48,49]$. Risk perception should be a consideration in wildlife tourism for both management and policy [50].

Research on risk perception focuses on types of risks, including the risks involved in particular travel experiences such as adventure and sports tourism [51,52], and the measurement of risk perception levels. The more common risk perception models include the following factors: hardware/facilities, physical health, money/finance, expectations, 
social relationships, time costs, and political dynamics [53-56]. Perceptions of risk were found to vary with tourists' age, income, family status, travel experience, partnering style, length of stay, travel expenses, satisfaction, travel frequencies, willingness to travel, sensation seeking, holiday needs and intercultural communication efforts [57,58]. Gustafson $(1998)[48,59]$ suggested that women and men may perceive risk differently. However, there is a lack of gender-informed risk-focused investigations [11] and most studies of risk and gender have prioritized the experiences in or from developed countries.

With respect to wildlife, Cong et al. (2017) [2] identified three risk factors in humandolphin interactions: quality of experience, physical risk and amenity risk. Perceptions of risk are influenced by the species, the size of the animal, the degree to which wildlife is considered to be dangerous, whether species are diurnal or nocturnal, and the degree of control individuals feel that they have over wildlife activities [40,60]. Wildlife-human interactions associated with hunting have also been explored where the perceived risks can be indirectly influenced by management action and information dissemination [61]. The higher the perceived risk, the lower the likelihood of travel to a destination as potential visitors become more cautious and rational $[62,63]$. Therefore, understanding the risk sensitivity of tourists in different situations, and providing them with health and safety protection when necessary, have become important to the construction and marketing of destinations.

In summary, decision-making behavior and risk perception are important but underexplored in wildlife tourism research. There is also a need to address these topics from a gendered perspective.

\subsection{Research Hypotheses}

Much related research on risk and destination choice focuses on specific destinations in an isolated way, resulting in a fragmented nature in research results without a comprehensive understanding [58]. Thus, a more complete understanding of the entire process of wildlife tourism can be obtained by exploring the roles of women in the multiple stages of decision-making. In the study of tourists' participation in tourism decision-making, scholars often subdivide tourism into different stages and study the specific content of tourism decision-making in these stages [13]. This may explain some of the differences in results obtained in other studies [38]. Accordingly, the decision-making content of wildlife tourism is divided into four chronological stages, which involve different activities, thereby providing specific information for various service suppliers in wildlife tourism. Studies have confirmed that the higher the risk perception of potential tourists to a destination, the less likely they will travel there [64]. Karl (2018) [65] Subdivided the type of destination from tourist risk perception: Familiarity, (Touristic) infrastructure, Safety and verified that tourists with varying attitudes toward risk and uncertainty in travel decision-making differ strongly with respect to ideal destinations initially, but choose rather similar destinations when it comes to the final destination choice. However, this relationship has not been examined previously according to different stages of decision-making behavior and with different types of risk.

In this research, the following four sequential decision-making stages are examined: pre-trip travel planning, destination selection, form of travel and safety concerns, and entertainment consumption during the trip [13]. Risk perception is subdivided into three types: physical safety, comfort and experience quality [37]. Thus, the following hypotheses are proposed:

Hypothesis 1-1. (H1-1): Perceived physical safety risk significantly affects pre-trip travel planning decision-making.

Hypothesis 1-2. (H1-2): Perceived physical safety risk significantly affects tourism destination selection decision-making. 
Hypothesis 1-3. (H1-3): Perceived physical safety risk significantly affects decision-making regarding form of travel and safety concerns.

Hypothesis 1-4. (H1-4): Perceived physical safety risk significantly affects decision-making concerning entertainment consumption during the trip.

Hypothesis 2-1. (H2-1): Perceived risk to comfort significantly affects pre-trip travel planning decision-making.

Hypothesis 2-2. (H2-2): Perceived risk to comfort significantly affects tourism destination selection decision-making.

Hypothesis 2-3. (H2-3): Perceived risk to comfort significantly affects decision-making regarding form of travel and safety concerns.

Hypothesis 2-4. (H2-4): Perceived risk to comfort significantly affects decision-making concerning entertainment consumption during the trip.

Hypothesis 3-1. (H3-1): Perceived experience quality risk significantly affects pre-trip travel planning decision-making.

Hypothesis 3-2. (H3-2): Perceived experience quality risk significantly affects tourism destination selection decision-making.

Hypothesis 3-3. (H3-3): Perceived experience quality risk significantly affects decision-making regarding form of travel and safety concerns.

Hypothesis 3-4. (H3-4): Perceived experience quality risk significantly affects decision-making concerning entertainment consumption during the trip.

\subsection{Research Model}

According to the literature review and the hypotheses, it is proposed that the relationships between the perceived risk of physical safety, perceived risk to comfort, and perceived risk to experience quality, and the four stages of decision-making, are as shown in Figure 1 below.

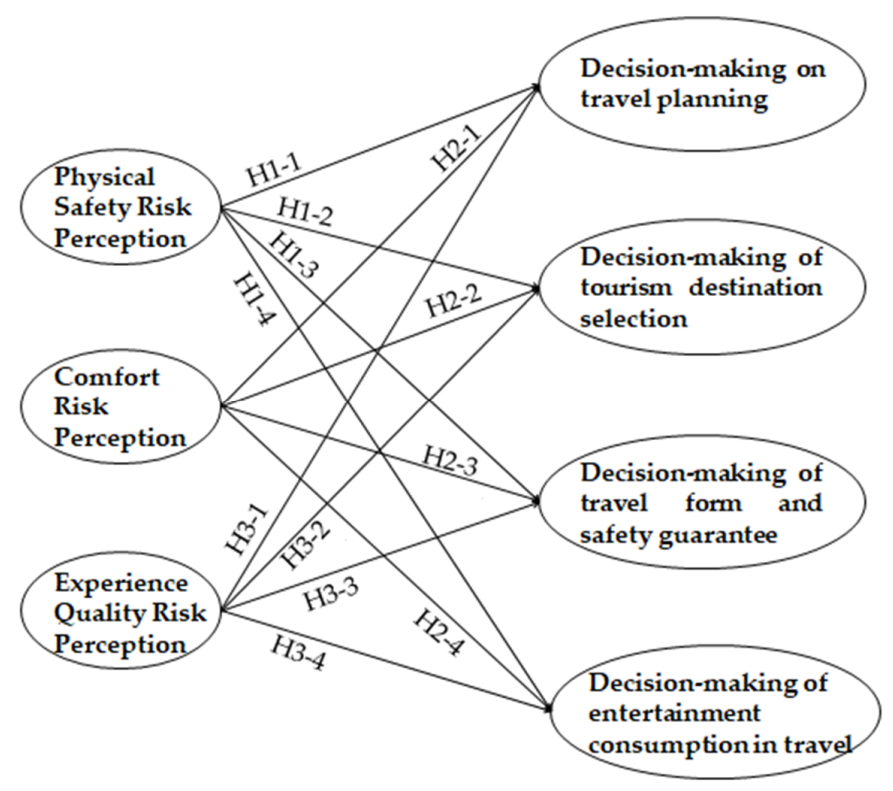

Figure 1. Conceptual framework. 


\section{Questionnaires Design and Analytical Methods \\ 3.1. Questionnaires Design}

A questionnaire was designed on decision-making behavior and risk perception in wildlife tourism, composed of five parts: decision-making influences, decision-making content in each tourism stage, risk perception, travel behavior and demographic information.

First, respondents were asked who is dominant in wildlife tourism decisions and the role of their peers in such decisions. In order to determine the degree of decision-making participation of women in wildlife tourism, the process of wildlife tourism was divided into different sequential stages (initial preparation, pre-trip financing, pre-departure arrangements and destination activities). Each was addressed through 4-6 items, for a total of 19 questions, based upon the content on women's tourism decision-making in Zalatan (1996) [43], and informed by a review of the websites of many wildlife destinations in China. Respondents answered using 5-point Likert scales. Risk perception was measured using nine items taken from Roehl and Fesenmaier (1992) [56], Lepp and Gibson (2003) [14], Lepp, Gibson and Lane (2011) [54] and Xu, Cong and Wall (2019) [28], each with five options from $1=$ "not worried at all" to $5=$ "very worried". SPSS20.0 software was used to test the reliability and validity of the questionnaire. The reliability is 0.873 which is high and the $\mathrm{KMO}$ value exceeds 0.8 which indicates good validity.

The content of the questionnaire addressed decision-making in the following four stages: First, the initial preparation activities, when travel information is collected and the destination and duration of the trip are determined. Second, financial management activities are usually considered before travel. Travel is an expensive leisure activity, and for some groups, it may be the most expensive service product they have ever purchased. Therefore, the pre-departure budget and the purchase of services from travel agents and operators, etc. is particularly important. Third, arrangements are made prior to the departure. Before the departure, the tourist arranges accommodation, transportation, luggage and insurance according to their own situation and that of their companions. Fourth, once tourists arrive at the destination, they will make decisions about more tourism activities, including the selection of scenic spots, interpretation systems, restaurants, shopping and entertainment. A total of 19 decision-making items are identified as occurring in the four stages.

\subsection{Data Collection}

The population of wildlife tourists is unknown, but includes those who travel specifically in the hope of seeing wildlife as well as those for whom it is a subsidiary, even incidental, experience. Thus, there is no obvious way of gaining a representative sample. Initially, a total of 12 groups of tourists was interviewed in Sichuan Wolong Nature Reserve, in Sichuan, China, where animals live in a natural environment, and in Beijing Badaling Wildlife World, which is a drive-through safari park, to gain information to assist in the design of the questionnaire. Questionnaires were administered at these two sites from 3 April to 18 April 2018. Purposive sampling and spot intercept at the entrance of the scenic spot strategy were used for the questionnaire distribution. It was recognized that when interviewing women in the field, if other members of the party, such as husbands and children, participate, then answers may be modified and the data may be contaminated. This could not be avoided entirely but every effort was made to encourage interviewees to speak freely and to avoid this form of bias. In this study, 49 respondents completed questionnaires at the former site and 114 at the latter. In order to ensure the quality of the questionnaire filling, each questionnaire was filled out on the spot and collected as soon as they finished. Each questionnaire was completed with the guidance of our research team members face to face during the whole process in case of any introduction or explanation was needed. To express gratitude, every respondent will get a small gift. The recovery rate was $100 \%$. In order to reduce the interference to the quality of tourists' travel experience, no continued interruption to those non-respondents if they showed reluctance to complete it. Thus, visitors to both non-captive and semi-captive wildlife sites are included in the study. However, the majority (252) of respondents are self-selected, responding to an internet 
website posting. The responses are analyzed as one dataset. While an effort was made to ensure that a diversity of experiences and locations is included in the sample, it cannot be claimed that the sample of 415 respondents is representative of all wildlife tourists in China. Therefore, the results of this study are indicative rather than conclusive.

\subsection{Statistical Analysis}

A predominantly quantitative approach is employed using Excel, SPSS20.0 and AMOS24.0 software. First, descriptive statistics are used to summarize respondents' demographic and travel behavior characteristics. Then, factor analysis is used to compress the risk perception and decision participation scales. Correlation analysis is used to explore relationships between both demographic and travel characteristics with participation in decision-making. Relationships between decision-making behavior education, number of children, age, income, travel duration, travel cost and so on were tested using correlation analysis. Structural Equation Modeling (SEM) permits the analysis of linear relationships between manifest variables and latent constructs [66,67]. AMOS24.0 software was used to test the SEM of the relationship between tourism risk perception and participation in tourism decision-making. Several indices were used, such as $\chi^{2} / \mathrm{df}$, the goodness of fit index (GFI), adjusted goodness of fit index (AGFI), normative fit index (NFI), comparative fit index (CFI), root mean square residual (RMR), and root mean square error of approximation (RMSEA) [8].

\section{Results}

\subsection{Attributes of Respondents and Travel Characteristics}

\subsubsection{Attributes of Respondents}

Most of the female tourists are younger than 45 years (Table 1). They are highly educated and about a quarter are students. As a result, many have a low income. The number of low-income groups is larger than that of high-income groups. Almost half $(45.3 \%)$ have no children and, reflecting past Chinese policy, a similar proportion (43.4\%) have one child. Most respondents come from Shaanxi, Beijing and Sichuan.

Table 1. Demographics attributes of female tourists $(\mathrm{N}=415)$.

\begin{tabular}{ccc}
\hline Subject & Attribute Level & Percentage (\%) \\
\hline \multirow{3}{*}{ Age } & $<25$ & 33.1 \\
& $25-34$ & 24.9 \\
& $35-44$ & 28.9 \\
& $45-54$ & 9.9 \\
& $\geq 55$ & 3.4 \\
\hline \multirow{2}{*}{ Job } & Self-employed/Business & 5.3 \\
& owner & 5.1 \\
& Manager & 36.1 \\
& Common employees & 11.1 \\
& Technical personnel & 10.8 \\
& Liberal professions /Full-time & 4.3 \\
& housewife & 27.2 \\
\hline \multirow{2}{*}{ Educational Level } & Retiree & 1.7 \\
& Student & 9.4 \\
& Junior high school and below & 22.9 \\
& Senior school or technical & 46.3 \\
& secondary school & 19.8 \\
\hline
\end{tabular}


Table 1. Cont.

\begin{tabular}{ccc}
\hline Subject & Attribute Level & Percentage (\%) \\
\hline \multirow{3}{*}{ Number of children } & No children & 45.3 \\
& One & 43.4 \\
& Two & 11.1 \\
& Three or more & 0.2 \\
\hline \multirow{3}{*}{ Annual income (Yuan) } & $<30,000$ & 34.9 \\
& $30,000-50,000$ & 23.1 \\
& $50,001-100,000$ & 19.8 \\
& $100,001-200,000$ & 12.8 \\
& $200,001-300,000$ & 5.3 \\
& $>300,000$ & 4.1 \\
\hline
\end{tabular}

\subsubsection{Travel Characteristics}

Respondents indicated that they mostly travel once per year for less than 3 days. They prefer affordable hotels rather than star hotels or other types of accommodation. Independent travel with family, husbands or boyfriends, as well as with colleagues, classmates and friends, are preferred to organized tours. Less than $10 \%$ travel to view wildlife through a travel agency. They travel for sightseeing, relaxation and to understand wildlife. Nearly two-thirds indicated that they seek information through new media, such as Weibo and WeChat, although recommendations of relatives and friends are also important. Expenditures are not large (more than half spend less than a thousand dollars on wildlife travel) even though there is interest in purchasing souvenirs, such as clothes and hats. Semicaptive breeding locations, such as safari parks, are the preferred destinations. Watching wildlife from a distance and seeing specimens in museums are the most common forms of wildlife tourism in China.

\subsection{Decision-Making Participation}

\subsubsection{Female Travelers' Decision-Making Influence}

According to the survey, in the wildlife tourism situation, about one-third of the women interviewed are willing to listen to the opinions of classmates, colleagues and friends. More than a quarter are willing to listen to their boyfriends or husbands. More than one-fifth is unwilling to listen to the opinions of others. The proportion of people who are willing to listen to their parents $(10.8 \%)$ and the elderly and children $(7.2 \%)$ is small. Only $13 \%$ of respondents relied completely on the opinions of their peers. The data reveal the complexity of decision-making and a widespread willingness to consider the opinions of others but, ultimately, more than half give priority to their own wishes.

\subsubsection{Female Tourists' Decision-Making Participation}

Mean scores for decision-making participation, derived from Likert scales ( 5 is full participation, 0 is non-participation), are shown in Table 2. All scores are above 3.0 and the average of these scores is 3.57 , confirming the importance of women in the decisionmaking process.

In previous studies, women generally participated most in decisions on destination activities, but the results of this survey are different: the average score (3.49) for destination activities is lower than the overall average score (3.57). In this study, involvement in choosing a tour guide and commentary system and choosing shopping is low (3.14 and 3.22 , respectively). Compared with men, in general, female tourists are less likely to be sightseers. Additionally, they are not strong seekers of wildlife knowledge so they have low inputs into decision-making regarding guides and interpretation. In both daily life and during travel, shopping is an activity that can bring entertainment and excitement to women. If with a child, they will listen to the child's opinion, but shopping at wildlife tourism scenic spots is not an important activity for women, and their involvement in this activity is low. 
Table 2. Level of participation in decisions.

\begin{tabular}{|c|c|c|c|}
\hline \multicolumn{2}{|c|}{ Subdivision Decision Content } & Level of Participation & Standard Deviation \\
\hline \multirow{6}{*}{ Initial preparation activities } & Decide on the date of the holiday & 3.67 & 1.15 \\
\hline & Pick destination & 3.87 & 1.13 \\
\hline & $\begin{array}{l}\text { Search for wildlife tourism } \\
\text { information }\end{array}$ & 3.55 & 1.06 \\
\hline & Search for destination information & 3.79 & 1.10 \\
\hline & Search for travel agency information & 3.26 & 1.23 \\
\hline & Subtotal & 3.63 & 0.88 \\
\hline \multirow{5}{*}{ pre-trip financing } & Budget and financial arrangement & 3.61 & 1.10 \\
\hline & Registration travel agency & 3.13 & 1.28 \\
\hline & Buy airline tickets and train tickets & 3.56 & 1.20 \\
\hline & Buy tourist attractions tickets & 3.57 & 1.17 \\
\hline & Subtotal & 3.47 & 0.95 \\
\hline \multirow{5}{*}{ Pre-departure arrangements } & Transport arrangements & 3.60 & 1.15 \\
\hline & Accommodation arrangements & 3.74 & 1.14 \\
\hline & Prepare luggage & 4.02 & 1.08 \\
\hline & $\begin{array}{c}\text { Other arrangements (e.g., medical } \\
\text { insurance) }\end{array}$ & 3.33 & 1.26 \\
\hline & Subtotal & 3.67 & 0.92 \\
\hline \multirow{7}{*}{ Destination activities } & Choose tourist attractions & 3.88 & 1.00 \\
\hline & $\begin{array}{l}\text { Choosing tour guides and } \\
\text { commentary system }\end{array}$ & 3.14 & 1.92 \\
\hline & Choose restaurants & 3.64 & 1.10 \\
\hline & Shopping activities & 3.22 & 1.25 \\
\hline & Entertainment activities & 3.53 & 1.12 \\
\hline & Treat emergencies & 3.54 & 1.13 \\
\hline & Subtotal & 3.49 & 0.80 \\
\hline \multicolumn{2}{|c|}{ Average } & 3.57 & 1.15 \\
\hline
\end{tabular}

Women participate actively in pre-departure activities (mean $=3.67)$. They are particularly prominent in preparing the luggage (4.02), which received the highest score among all measured activities. They are also prominent in making accommodation and travel arrangements. In the final decisions before departure, women are often able to make detailed arrangements in terms of transportation and accommodation, re-confirming prior information.

Of the major groups of decision-making activities, when their constituent responses are averaged, the lowest participation is in pre-trip financing (3.47). However, there are significant differences between those with and without an income. For example, retired women (2.57) and housewives (3.21) have the lowest degree of financial decision-making. The score for students is only 3.29. In contrast, professional and technical personnel (3.72) and enterprise managers (3.68) have higher scores. Thus, those with independent income sources have greater decision-making roles in pre-departure financial management activities, whereas those with few economic resources negotiate with others rather than making decisions themselves.

The educational level of female tourists and their degree of tourism decision-making are significantly correlated at the 0.01 level. Linear regression analysis produced a positive coefficient of 0.218 . Therefore, the higher the educational level, the greater is the likelihood of involvement in decision-making in wildlife tourism, especially in more complex decisions. Well-educated women have more ability and greater economic power and pay more attention to their own needs.

Number of children is significantly correlated with the degree of tourism decisionmaking at the 0.05 level. Linear regression resulted in a coefficient of -0.106 , indicating those with more children tend to have less involvement in decision-making. Although both women and men take the initiative to deal with trivial matters, caring for children consumes 
a lot of energy for women, especially when there is more than one child in the family. This preoccupation causes them, when traveling, to give less attention to decisions regarding tourism activities and to give greater priority to the child's wishes. Unmarried women and those who are not pregnant are more likely to make independent travel decisions.

Length of time spent at the destination and involvement in decision-making are correlated at the 0.01 level with a positive linear regression coefficient of 0.134 . The longer the trip, the more complex the decisions and the more decisions are required, for instance with respect to entertainment and shopping, and the greater the chance of involvement. Similarly, there is also a significant correlation (at the 0.01 level) between travel expenses and the degree of tourism decision-making with a linear regression coefficient of 0.144 . Not only is greater attention given to trips with greater costs, but those with higher tourism expenditures also tend to have higher education and more tourism experience and are more adept at making tourism decisions.

Somewhat surprisingly, neither age nor income was found to be related significantly to the degree of female decision-making in tourism. As young women age and have increased family responsibilities, they pay more attention to the needs and preferences of spouses, children and other family members, and consider more the opinions of others when making tourism decisions. At the same time, they may make more detailed decisions, such as packing luggage or selecting a restaurant, while leaving many decisions to others. With respect to income, women with higher incomes often have richer tourism experiences and can make informed and efficient tourism decisions. In addition, women with high incomes generally have stronger voices in family matters, making participation in tourism decisions more prominent. In contrast, female tourists with lower incomes cherish a relatively small number of tourism opportunities. They check the information carefully and pay more attention to details in the tourism process in order to reduce risk and to try to ensure that they have a high-quality tourism experience. This results in higher decision-making participation. Thus, no clear relationship between income and tourism decision-making was found.

\subsection{Risk Perception and Decision Participation}

\subsubsection{General Characteristics}

Female tourists were most worried about the safety of wildlife tourism and tourism projects, with an average score of 3.81 (out of 5), followed by road safety. They were less concerned about the lack of opportunities to see wildlife at the destination, inconvenient weather conditions or unsatisfactory travel arrangements.

Initially, risk perception and decision participation are analyzed separately and then the relationship between them is explored.

\subsubsection{Risk Perception}

Because there are nine items in the questionnaire concerning risk perception and 19 items regarding participation, factor analysis is used to group the data into a small number of meaningful combinations and eliminate less important information. First, the suitability of the data for factor analysis was confirmed using the KMO and Butler spherical tests. The $\mathrm{KMO}$ value of the risk perception items is 0.872 , which is greater than the critical value of 0.7 . Cronbach's $\alpha=0.86$, indicating that there are common factors among the correlation matrices of the risk perception items, confirming that the data are suitable for factor analysis. Factor analysis was conducted using SPSS24.0. Factors were obtained according to the principal component extraction method, with orthogonal rotation with maximum variance. Three risk components were found with eigenvalues greater than 0.5 and they are named physical safety risk, comfort risk and experience quality risk (Table 3 ). The cumulative variance of the three factors is $75.7 \%$, i.e., the three factors summarize $75.7 \%$ of the information contained in the original variables. 
Table 3. Risk perception factor analysis results.

\begin{tabular}{|c|c|c|c|c|}
\hline New Extraction Factor & Problem Item & Factor Loading & $\begin{array}{l}\text { Interpretation of } \\
\text { Variance }\end{array}$ & \\
\hline \multirow{3}{*}{ Physical safety risk } & $\begin{array}{l}\text { Worried that wildlife } \\
\text { threatens personal safety }\end{array}$ & 0.892 & \multirow{3}{*}{53.108} & \\
\hline & $\begin{array}{l}\text { Worried that tourism projects } \\
\text { endanger personal safety }\end{array}$ & 0.849 & & $\mathrm{KMO}=0.872$ \\
\hline & $\begin{array}{l}\text { Worried about various } \\
\text { accidents on the road that } \\
\text { endanger personal safety }\end{array}$ & 0.784 & & $\begin{array}{l}\text { Bartlett }=1942.601 \\
\text { Freedom }=36 \\
\text { Sig. }=0.000\end{array}$ \\
\hline \multirow[t]{2}{*}{ Comfort risk } & $\begin{array}{l}\text { Worried about the climatic } \\
\text { conditions of the destination, } \\
\text { such as dissatisfaction }\end{array}$ & 0.842 & \multirow[t]{2}{*}{14.235} & \\
\hline & $\begin{array}{l}\text { Worried about poor } \\
\text { destination infrastructure } \\
\text { Worried about the }\end{array}$ & 0.739 & & \\
\hline \multirow{3}{*}{ Experience quality risk } & $\begin{array}{c}\text { inconvenience of destination } \\
\text { traffic }\end{array}$ & 0.590 & \multirow{3}{*}{8.359} & \\
\hline & $\begin{array}{l}\text { Worried about the chances of } \\
\text { seeing wild animals }\end{array}$ & 0.918 & & \\
\hline & $\begin{array}{l}\text { Worried that the travel } \\
\text { experience has not met } \\
\text { expectations }\end{array}$ & 0.810 & & \\
\hline
\end{tabular}

\subsubsection{Decision Participation}

As for the risk perception data, the suitability of the decision participation data for factor analysis was tested using KMO and Butler spherical tests. The KMO for decisionmaking participation is 0.916 , which is greater than 0.7 and Cronbach's $\alpha=0.83$. This indicates suitability for factor analysis. Using the same procedures as above for the risk perception data and an eigenvalue of 1 , four components were derived from 19 items (Table 4). These are named: destination selection, travel method and security, pre-tour travel decision-making, and entertainment consumption. The cumulative variance of the four factors is $65.2 \%$. The results confirm that the involvement of women is most prominent in the pre-trip phase.

\subsection{Structural Equation Model (SEM)}

An SEM was created to investigate the relationship between tourism risk perception and tourism decision participation. A set of hypotheses was created, and they are shown in Table 5. The KMO is 0.876 , Cronbach's $\alpha=0.85$. Harman's single factor test $=19 \%, p<0.05$ was used as the standard to test the hypotheses. The initial model underwent three rounds of corrections, and the structure of the final model is presented in Table 6 . The model fits acceptable standards according to $\chi^{2} / \mathrm{df}, \mathrm{GFI}, \mathrm{CFI}$, IFI, and RMSEA. It is very close to the NFI standard. The critical value is greater than 1.96, and it is significant at the 0.05 level. Therefore, the structural equation model fits well. The test results are shown in Table 6 and the final model is presented in Figure 2. 
Table 4. Decision participation factor analysis results.

\begin{tabular}{|c|c|c|c|c|}
\hline Factors & Items & Factor Loading & $\begin{array}{l}\text { Interpretation of } \\
\text { Variance }\end{array}$ & \\
\hline \multirow{6}{*}{$\begin{array}{l}\text { Pre-tour Travel } \\
\text { Decision-making }\end{array}$} & $\begin{array}{l}\text { Budget and financial } \\
\text { arrangements }\end{array}$ & 0.511 & \multirow{6}{*}{44.739} & \\
\hline & Buy air, train, bus tickets & 0.803 & & \\
\hline & $\begin{array}{l}\text { Purchase tickets for scenic } \\
\text { spots }\end{array}$ & 0.817 & & \\
\hline & $\begin{array}{l}\text { Search and arrangement of } \\
\text { traffic information }\end{array}$ & 0.737 & & \\
\hline & $\begin{array}{l}\text { Search and arrangement of } \\
\text { accommodation information }\end{array}$ & 0.714 & & \\
\hline & Prepare luggage & 0.534 & & \\
\hline \multirow{5}{*}{ Destination Selection } & $\begin{array}{l}\text { Decide on the date and } \\
\text { duration of the holiday }\end{array}$ & 0.648 & \multirow{5}{*}{8.188} & $\mathrm{KMO}=0.916$ \\
\hline & Selection of destinations & 0.774 & & Bartlett $=4369.378$ \\
\hline & Selection of tourist attractions & 0.597 & & $\begin{array}{l}\text { Freedom }=1 / 1 \\
\text { Sig. }=0.000\end{array}$ \\
\hline & $\begin{array}{l}\text { Inquiry of wildlife tourism } \\
\text { information }\end{array}$ & 0.740 & & \\
\hline & $\begin{array}{l}\text { Search for destination } \\
\text { information }\end{array}$ & 0.760 & & \\
\hline \multirow{5}{*}{$\begin{array}{l}\text { Travel Method and } \\
\text { Security }\end{array}$} & $\begin{array}{l}\text { Inquiry of travel agency } \\
\text { information }\end{array}$ & 0.788 & \multirow{5}{*}{6.584} & \\
\hline & Sign up for a tour group & 0.807 & & \\
\hline & $\begin{array}{l}\text { Choosing tour guides and } \\
\text { persuasion services }\end{array}$ & 0.529 & & \\
\hline & $\begin{array}{l}\text { Arrangement of medical and } \\
\text { insurance items }\end{array}$ & 0.520 & & \\
\hline & $\begin{array}{c}\text { Treatment of special and } \\
\text { unexpected events }\end{array}$ & 0.503 & & \\
\hline \multirow{3}{*}{$\begin{array}{l}\text { Entertainment } \\
\text { Consumption }\end{array}$} & Choose restaurant & 0.647 & \multirow{3}{*}{5.729} & \\
\hline & Choose shopping activities & 0.843 & & \\
\hline & Choose recreational activities & 0.792 & & \\
\hline
\end{tabular}

Table 5. Hypothesis test results.

\begin{tabular}{cc} 
Hypothesis & Conclusion \\
\hline H1-1: Risk perception positively impacts & accepted \\
decision-making behavior & accepted \\
H1-2: Physical safety risk positively impacts & accepted \\
travel method and safety guarantee & \\
H1-3: Comfort risk perception positively & \\
impacts pre-trip planning decisions & accepted \\
H1-4: Comfort risk perception significantly & \\
positive impact decision-making of tourism & \\
destination selection & accepted \\
positive impact decision-making of & \\
entertainment consumption in travel & \\
H2-2: Experience quality risk perception & accepted \\
significantly positive impact decision-making & \\
of entertainment consumption in travel &
\end{tabular}


Table 6. Model structure and fit.

\begin{tabular}{|c|c|c|c|c|c|c|}
\hline \multicolumn{3}{|c|}{ Variables } & $\begin{array}{l}\text { Standardized } \\
\text { Estimation }\end{array}$ & Standard Error & Critical Value & $p$-Value \\
\hline \multicolumn{3}{|c|}{$\begin{array}{l}\text { Decision-Making of Travel Form and Safety Guarantee } \\
\qquad \leftarrow \text { Physical safety risk }\end{array}$} & 0.237 & 0.056 & 4.223 & $* * *$ \\
\hline \multicolumn{3}{|c|}{$\begin{array}{c}\text { Decision-making on travel planning before Tourism }< \\
\qquad \text { Comfort risk }\end{array}$} & 0.176 & 0.048 & 3.660 & $* * *$ \\
\hline \multicolumn{3}{|c|}{$\begin{array}{c}\text { Decision-Making of Tourism Destination Selection }< \\
\leftarrow \text { Comfort risk }\end{array}$} & 0.188 & 0.051 & 3.715 & $* * *$ \\
\hline \multicolumn{3}{|c|}{$\begin{array}{c}\text { Decision-making of Entertainment Consumption in } \\
\text { Travel }<\leftarrow \text { Comfort risk }\end{array}$} & 0.128 & 0.053 & 2.418 & $* *$ \\
\hline \multicolumn{3}{|c|}{$\begin{array}{c}\text { Decision-making of Entertainment Consumption in } \\
\text { Travel }<\longleftarrow \text { Experience quality risk }\end{array}$} & 0.122 & 0.047 & 2.623 & $* *$ \\
\hline Index & $\chi^{2} / \mathrm{df}$ & GFI & CFI & NFI & IFI & RMSEA \\
\hline Analysis result & 4.214 & 0.813 & 0.824 & 0.783 & 0.806 & 0.062 \\
\hline Ideal standard & $1<5$ & $>0.80$ & $>0.80$ & $>0.80$ & $>0.80$ & $<0.08$ \\
\hline
\end{tabular}

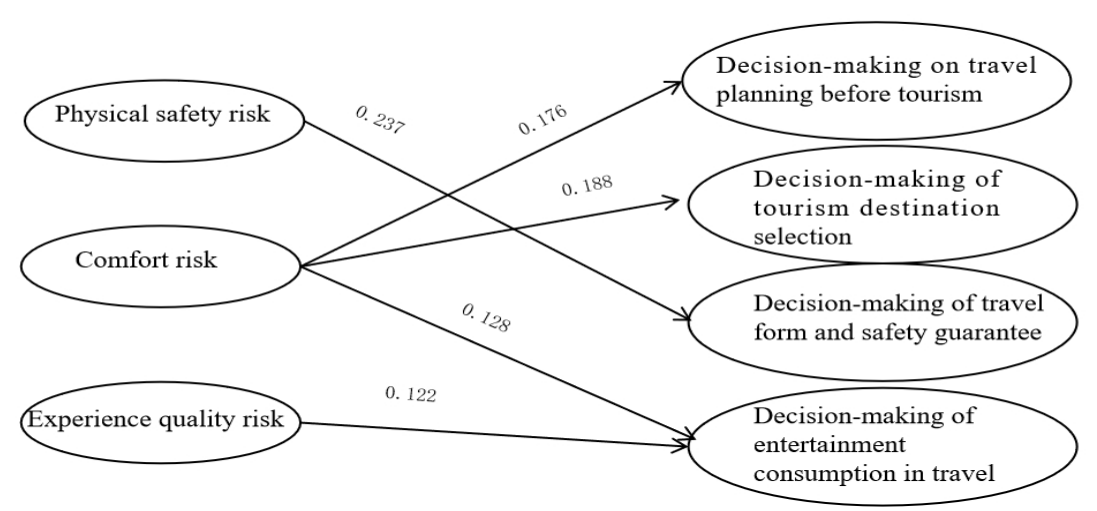

Figure 2. The SEM of risk perception and decision-making.

The SEM results are basically consistent with the linear regression results. For example, for female wildlife tourists, physical safety concerns significantly affect travel method and security decisions; risks related to the quality of experience significantly affect decisions regarding entertainment/recreation activities. Small differences between model results and prior analyses probably reflect the fact that the extracted factors used in the SEM cannot fully represent the actual situation due to the loss of information involved in factor analysis.

\section{Discussion}

Wildlife tourism has gained increasing research attention globally [68]. Tourists' attitudes and behavior regarding wildlife are vital aspects of the sustainable development of wildlife tourism. The development of wildlife tourism in China is facing great opportunities and challenges [28]. This research explored women's decision-making behavior and their perceptions of risk in wildlife tourism using quantitative research methods.

Women have important and increasing influences in wildlife tourism decision-making which occurs in four stages, reflecting their expanded power in the family and society in China. The finding that women participate actively in destination selection and predeparture activities is consistent with the finding of other research, such as Wang et al., (2004) [41] and Kim et al. (2010) [58]. However, in previous studies, such as Kim et al. (2010) [58], women participated most in decisions on destination activities, but the results of this survey are different. Their decision-making level in shopping in the wildlife context is low, probably reflecting the generally poor shopping environment in such situations. While most wildlife tourism spots in China have souvenir shops, few types of goods are available, and their appearance and quality and the creativity behind the products are not attractive to most female tourists. Research on the shopping behavior of female tourists 
indicates that they are often drawn to attractions with shopping opportunities and they generally spend more time and energy on shopping than male tourists [69] and are more willing to buy souvenirs than men [70]. They prefer to purchase souvenirs, such as clothes and hats, which are aesthetically valuable, compared to educational products such as books and postcards. They prefer to read travel reviews rather than the basic information provided by travel websites [71].

Women with higher education participate more in tourism decision-making, this conclusion is consistent with Antoine's (1998) [13] and Karl's (2018) [65] findings. Additionally, the more children they have the less likely they are to be involved in decision-making. This finding supports the results of Filiatrault (1980) [10] on the influence of family structure on women's behavioral decisions. They are also more likely to be involved when trips are relatively long and expensive. No significant relationship was found with age or income, perhaps because most respondents were relatively young adults and only 11 percent of respondents were aged 45 years or older This is inconsistent with previous studies $[57,58]$. Nichols and Snepenger (1998) [29] show that family income also affects women's travel decisions: specifically, decisions in low-income families are dominated by the wife, while in middle-income families they are jointly made by the husband and wife.

Female wildlife tourists are most worried about physical safety, such as being harmed by wild animals. This is different from female solo travelers who are pursuing risktaking experiences [11]. In recent years, there have been widely publicized examples of injuries resulting from interactions with wildlife, demonstrating the need for managers to pay attention to the safety of their sites. The research findings are generally consistent with conclusions that the higher the perceived risk, the more cautious the decision, and female tourists are often more concerned than men about the security of accommodation, transportation and tour arrangements [18].

\subsection{Theoretical Contributions and Implications for Sustainable Tourism}

This study focused on the female tourism market in wildlife tourism and has portrayed the characteristics of the Chinese female role in wildlife tourism decision-making. A majority of risk and gender studies address the experiences of travelers from developed countries [1]. This study of Chinese wildlife tourists enriches the literature and complements the studies undertaken elsewhere in other cultural contexts. The focus on the analysis of the relationships between risk perception and decision-making behavior, contributes to risk theory, decision-making behavior theory and gender research.

\subsection{Practical Implications}

The sustainable development of wildlife tourism is a global challenge. The development of wildlife tourism in China is facing opportunities and challenges [27]. On the one hand, it is necessary to meet rapidly expanding tourist demands. China has a large population, and the protection of wildlife resources is under high pressure. The sustainable development of biodiversity and communities is at the core of sustainable tourism systems $[17,29]$. China is in the process of establishing a national park-based nature reserve system and there is a need to understand and manage the clientele [28]. Women have a higher perception of the risk of being harmed by wildlife. The higher the risk perception of potential tourists to a destination, the lower is the possibility that they will travel there. Wildlife tourist attractions should strengthen their safety precautions and take measures to protect the safety of tourists [4]. This research supports the sustainable development of wildlife tourism destinations, findings can inform site management and niche marketing.

Women are active in pre-tour destination selection and collection of information and wildlife tourist attraction managers and operators should not ignore the needs of women at this decision stage. They should use effective methods to attract female tourists, such as writing attractive advertisements and encouraging visitors to pass on word-of-mouth recommendations to their relatives and friends. 
Compared with men, women are more concerned about food safety and accommodation during travel. Therefore, tourism companies involved in wildlife tourism should ensure that they provide female tourists with safe and hygienic meals and lodgings. Female tourists are interested in the decision-making of shopping activities, and wildlife destinations with a good shopping and consumption environment will be more favored by female tourists. The development of creative cultural and creative products and souvenirs related to wild animals is an opportunity.

Perception of high risk makes tourists more cautious and rational. For example, after deciding to take a trip, they may collect a large amount of tourism information to enhance their sense of security. Understanding the risk perception characteristics of tourists in different tourism contexts can inform the provision of protection for them in various aspects, such as health and safety.

\subsection{Limitation and Future Research}

The database consists of visitors to specific sites as well as online questionnaires aimed at tourists' risk perception and decision-making on wildlife tourism experiences generally. This ensures a diversity of experiences at the cost of a representative sample of a known population. The results of this research are suggestive rather than definitive. In order to acquire a substantial number of respondents, it was necessary to use both on-site and internet surveys, and responses were analyzed as one sample. However, it is likely that visitors to different sites, particularly captive and non-captive wildlife settings, may have different attributes and display different behaviors with respect to both decision-making behavior and risk perception. Therefore, more research using consistent and comparable research methods, in a diversity of wildlife settings, is required. Future research can explore the differences in tourists' risk perception in captive, semi-captive and non-captive settings. Additionally, in focusing upon women, no attempt was made in this paper to explore the similarities and differences between men and women. In addition, this study did not differentiate between single household females, females with a partner without children, females without a partner with children and females with both a partner and children. Therefore, it is necessary to conduct in-depth research on each category of female tourism decision-making behavior in future research.

\section{Conclusions}

This study addressed a significant research gap: understanding female wildlife tourists, especially in China. It also takes an essential first step to examine the links between risk perception and decision-making behavior in wildlife tourism. It shows that female wildlife tourists have considerable involvement in decisions regarding wildlife tourism, especially in the pre-departure phase and when risks are perceived to be substantial.

A specialist group of wildlife tourists has yet to evolve in China. The portraits of wildlife tourists are described. Ranked according to the extent of female involvement in decisionmaking from high to low, their influence is greatest in destination selection, followed by pre-departure travel planning, travel form and safety, and entertainment consumption.

Correlation analysis was used to explore relationships between both demographic and travel characteristics with participation in decision-making. Education, number of children, age, income, travel duration, travel cost and so on were used to test relationships between them and decision-making behavior.

Regarding risk perception, three factors were extracted based on factor analysis of nine risk perception items: physical safety, comfort, and experience quality.

Women are prominent in collecting background information and participate actively in destination selection. They are more concerned with safety than men and are also more likely than men to desire a comfortable experience. Female tourists are prominent in shopping decisions. This suggests that wildlife tourism destinations with good shopping and other recreational/consumption opportunities will be most popular among female tourists. It also suggests the value of offering creative, animal-related products for sale. 
Supplementary Materials: The following are available at https:/ / www.mdpi.com/article/10.339 0/su131810301/s1, Table S1: The original data, Table S2: Correlation analysis, Table S3: Regression analysis, Table S4: Regression analysis (final).

Author Contributions: Conceptualization, L.C and G.W.; Data curation, L.C. and Q.W.; Formal analysis, Q.W.; Investigation, L.C. and Q.W.; Methodology, Q.W.; Validation, Y.S.; Writing-original draft, L.C.; Writing-review and editing, L.C., Y.S. and G.W. All authors have read and agreed to the published version of the manuscript.

Funding: This research was jointly funded by the National Natural Science Foundation of China, "Study on the Behavioral Characteristics and Regulation Mechanism of Chinese Wildlife Tourists" grant number 41601129; The Fundamental Research Funds of the Central University, "Spatio-temporal involvement and influencing factors of wildlife tourism", grant number 2021SRZ01.

Institutional Review Board Statement: The study was conducted according to the guidelines of the Declaration of Helsinki, and approved by the Institutional Review Board of Beijing Forestry University.

Informed Consent Statement: Informed consent was obtained from all subjects involved in the study.

Data Availability Statement: The data presented in this study are available in supplementary materials.

Acknowledgments: We are grateful to all our questionnair fillers for spending their time and efffforts on answering our questions. We thank external reviewers who helped to signifificantly improve this paper.

Conflicts of Interest: The authors declare no conflict of interest.

\section{References}

1. Movono, A.; Dahles, H. Female empowerment and tourism: A focus on businesses in a Fijian village. Asia Pac. J. Tour. Res. 2017, 22, 681-692. [CrossRef]

2. Cong, L.; Newsome, D.; Wu, B.; Morrison, A.M. Wildlife tourism in China: A review of the Chinese research literature. Curr. Issues Tour. 2017, 20, 1116-1139. [CrossRef]

3. Zhou, P.; Yang, X.L.; Wang, X.G.; Hu, B.; Zhang, L.; Zhang, W.; Si, H.R.; Zhu, Y.; Li, B.; Huang, C.L.; et al. A pneumonia outbreak associated with a new coronavirus of probable bat origin. Nature 2020, 579, 270-273. [CrossRef]

4. Cong, L.; Wu, B.; Zhang, Y.; Newsome, D. Risk Perception of interaction with dolphin in Bunbury, West Australia. Acta Sci. Nat. Univ. Pekin. 2017, 1, 179-188.

5. Panta, S.K.; Thapa, B. Entrepreneurship and women's empowerment in gateway communities of Bardia National Park, Nepal. J. Ecotourism 2018, 17, 20-42. [CrossRef]

6. Alarcón, D.M.; Cole, S. No sustainability for tourism without gender equality. J. Sustain. Tour. 2019, 27, 903-919. [CrossRef]

7. Kontogeorgopoulos, N. Wildlife tourism in semi-captive settings: A case study of elephant camps in northern Thailand. Curr. Issues Tour. 2009, 12, 429-449. [CrossRef]

8. Karl, M. Risk and uncertainty in travel decision-making: Tourist and destination perspective. J. Travel Res. 2016, 57, 129-146. [CrossRef]

9. Figueroa-Domecq, C.; Pritchard, A.; Segovia-Perez, M.; Morgan, N.; Villace-Molinero, T. Tourism gender research: A critical accounting. Ann. Tour. Res. 2015, 52, 87-103. [CrossRef]

10. Filiatrault, P.; Ritchie, J.R. Joint purchasing decisions: A comparison of influence structure in family and couple decision making units. J. Consum. Res. 1980, 7, 131-140. [CrossRef]

11. Yang, E.C.L.; Khoo-Lattimore, C.; Arcodia, C. A systematic literature review of risk and gender research in tourism. Tour. Manag. 2017, 58, 89-100. [CrossRef]

12. Moorhouse, T.P.; D'Cruze, N.C.; Macdonald, D.W. Are Chinese nationals' attitudes to wildlife tourist attractions different from those of other nationalities? J. Sustain. Tour. 2019, 27, 12-33. [CrossRef]

13. Antoine, Z. Wives' involvement in tourism decision processes. Ann. Tour. Res. 1998, 5, 890-930.

14. Lepp, A.; Gibson, H. Tourist roles, perceived risk and international tourism. Ann. Tour. Res. 2003, 30, 606-624. [CrossRef]

15. Newsome, D.; Rodger, K.; Pearce, J.; Chan, K.L.J. Visitor satisfaction with a key wildlife tourism destination within the context of a damaged landscape. Curr. Issues Tour. 2019, 22, 729-746. [CrossRef]

16. Seow, D.; Brown, L. The solo female Asian tourist. Curr. Issues Tour. 2018, 21, 1187-1206. [CrossRef]

17. Uduji, J.I.; Okolo-Obasi, E.N.; Asongu, S.A. Sustaining cultural tourism through higher female participation in Nigeria: The role of corporate social responsibility in oil host communities. Int. J. Tour. Res. 2020, 22, 120-143. [CrossRef]

18. Yang, E.C.L.; Khoo-Lattimore, C.; Arcodia, C. Constructing space and self through risk taking: A case of Asian solo female travelers. J. Travel Res. 2018, 57, 260-272. [CrossRef] 
19. Zhang, Y.; Hitchcock, M.J. The Chinese female tourist gaze: A netnography of young women's blogs on Macao. Curr. Issues Tour. 2017, 20, 315-330. [CrossRef]

20. Pizam, A. Research on Tourism Consumer Behavior; Northeast University of Finance and Economics Press: Dalian, China, 2005; pp. 97-112.

21. Shackley, M.L. Wildlife Tourism; International Tourism Business Press: Cambridge, MA, USA, 1996.

22. Kozak, M.; Crotts, J.C.; Law, R. The impact of the perception of risk on international travellers. Int. J. Tour. Res. 2007, 9, 233-242. [CrossRef]

23. Reynolds, P.C.; Braithwaite, D. Towards a conceptual framework for wildlife tourism. Tour. Manag. 2001, 22, 31-42. [CrossRef]

24. Mamula Nikolić, T.; Pantić, S.P.; Paunović, I.; Filipović, S. Sustainable travel decision-making of Europeans: Insights from a household survey. Sustainability 2021, 13, 1960. [CrossRef]

25. Øian, H.; Aas, Ø.; Skår, M.; Andersen, O.; Stensland, S. Rhetoric and hegemony in consumptive wildlife tourism: Polarizing sustainability discourses among angling tourism stakeholders. J. Sustain. Tour. 2017, 25, 1547-1562. [CrossRef]

26. Cheng, D.; Zhou, Y.; Wei, X.; Wu, J. A Study on the environmental risk perceptions of inbound tourists for China using negative IPA assessment. Tour. Trib. 2015, 30, 54-62.

27. Asmelash, A.G.; Kumar, S. Assessing progress of tourism sustainability: Developing and validating sustainability indicators. Tour. Manag. 2019, 71, 67-83. [CrossRef]

28. Xu, D.; Cong, L.; Wall, G. Tourists' spatio-temporal behaviour and concerns in park tourism: Giant Panda National Park, Sichuan, China. Asia Pac. J. Tour. Res. 2019, 24, 924-943. [CrossRef]

29. Nichols, C.A.; Snepenger, J.D. Family decision making and tourism behavior and attitudes. J. Travel Res. 1988, 26, 2-6. [CrossRef]

30. Ballantyne, R.; Packer, J.; Sutherland, L.A. Visitors' memories of wildlife tourism: Implications for the design of powerful interpretive experiences. Tour. Manag. 2011, 32, 770-779. [CrossRef]

31. Packer, J.; Ballantyne, R. Comparing captive and non-captive wildlife tourism. Ann. Tour. Res. 2012, 39, 1242-1245. [CrossRef]

32. Rodger, K.; Moore, S.A.; Newsome, D. Wildlife tourism, science and actor network theory. Ann. Tour. Res. 2009, 36, 645-666. [CrossRef]

33. Curtin, S. The self-presentation and self-development of serious wildlife tourists. Int. J. Tour. Res. 2010, 12, 17-33. [CrossRef]

34. D'Cruze, N.; Niehaus, C.; Balaskas, M.; Vieto, R.; Carder, G.; Richardson, V.A.; Macdonald, D.W. Wildlife tourism in Latin America: Taxonomy and conservation status. J. Sustain. Tour. 2018, 26, 1562-1576. [CrossRef]

35. Avila-Foucat, V.S.; Rodríguez-Robayo, K.J. Determinants of livelihood diversification: The case wildlife tourism in four coastal communities in Oaxaca, Mexico. Tour. Manag. 2018, 69, 223-231. [CrossRef]

36. Deng, F.G.; Long, G.L.; Liu, X.S. Two-step quantum direct communication protocol using the Einstein-Podolsky-Rosen pair block. Phys. Rev. A 2003, 68, 042317. [CrossRef]

37. Cong, L.; Wu, B.; Morrison, A.M.; Shu, H.; Wang, M. Analysis of wildlife tourism experiences with endangered species: An exploratory study of encounters with giant pandas in Chengdu, China. Tour. Manag. 2014, 40, 300-310. [CrossRef]

38. Kinnaird, V.; Hall, D. Understanding tourism processes: A gender-aware framework. Tour. Manag. 1996, 17, 95-102. [CrossRef]

39. Garg, A. Travel risks vs. tourist decision making: A tourist perspective. Int. J. Hosp. Tour. Syst. 2015, 8, 1-9. [CrossRef]

40. Ibnou-Laaroussi, S.; Rjoub, H.; Wong, W.K. Sustainability of green tourism among international tourists and its influence on the achievement of green environment: Evidence from North Cyprus. Sustainability 2020, 12, 5698. [CrossRef]

41. Wang, K.C.; Hsieh, A.T.; Yeh, Y.C.; Tsai, C.W. Who is the decision-maker: The parents or the child in group package tours? Tour. Manag. 2004, 25, 183-194. [CrossRef]

42. Wills, L.A. Family decision at the turn of the century: Has the changing structure of households impacted the family deci-sionmaking process. J. Consum. Behav. 2002, 22, 111-124.

43. Zalatan, A. The determinants of planning time in vacation travel. Tour. Manag. 1996, 17, 123-131. [CrossRef]

44. Qiu, F.; Wu, M. Research on factors affecting tourism decision-making. Psychol. Sci. 2004, 27, $1214-1217$.

45. Cahyanto, I.; Pennington-Gray, L.; Thapa, B.; Srinivasan, S.; Villegas, J.; Matyas, C.J.; Kiousis, S. An empirical evaluation of the determinants of tourist's hurricane evacuation decision making. J. Destin. Mark. Manag. 2014, 2, 253-265. [CrossRef]

46. Mardani, A.; Streimikiene, D.; Zavadskas, E.K.; Cavallaro, F.; Nilashi, M.; Jusoh, A.; Zare, H. Application of structural equation modeling (SEM) to solve environmental sustainability problems: A comprehensive review and meta-analysis. Sustainability 2017, 9, 1814. [CrossRef]

47. Tsaur, S.H.; Tzeng, G.H.; Wang, G.C. The application of AHP and fuzzy MCDM on the evaluation study of tourist risk. Ann. Tour. Res. 1997, 24, 796-812.

48. Gustafson, P.E. Gender differences in risk perception: Theoretical and methodological perspectives. Risk Anal. 1998, 18 , 805-811. [CrossRef] [PubMed]

49. Sönmez, S.F.; Graefe, A.R. Influence of terrorism risk on foreign tourism decisions. Ann. Tour. Res. 1998, 25, 112-144. [CrossRef]

50. Riley, S.J.; Decker, D.J. Risk perception as a factor in wildlife stakeholder acceptance capacity for cougars in Montana. Hum. Dimens. Wildl. 2000, 5, 50-62. [CrossRef]

51. Reichel, A.; Fuchs, G.; Uriely, N. Perceived risk and the non-institutionalized tourist role: The case of Israeli student exbackpackers. J. Travel Res. 2007, 46, 217-226. [CrossRef]

52. Wang, J.; Liu-Lastres, B.; Ritchie, B.W.; Pan, D.Z. Risk reduction and adventure tourism safety: An extension of the risk per-ception attitude framework (RPAF). Tour. Manag. 2019, 74, 247-257. [CrossRef] 
53. Feng, X. Women's work, men's work: Gender and tourism among the Miao in rural China. Anthropol. Work Rev. 2013, 34, 2-14. [CrossRef]

54. Lepp, A.; Gibson, H.; Lane, C. Image and perceived risk: A study of Uganda and its official tourism website. Tour. Manag. 2011, 32, 675-684. [CrossRef]

55. Lusseau, D.; Derous, D. Using taxonomically-relevant condition proxies when estimating the conservation impact of wildlife tourism effects. Tour. Manag. 2019, 75, 547-549. [CrossRef]

56. Roehl, W.S.; Fesenmaier, D.R. Risk perceptions and pleasure travel: An exploratory analysis. J. Travel Res. 1992, 30, 17-26. [CrossRef]

57. Aschauer, W. Perceptions of tourists at risky destinations. A model of psychological influence factors. Tour. Rev. 2010, 65, 4-20. [CrossRef]

58. Kim, S.S.; Choi, S.; Agrusa, J.; Wang, K.C.; Kim, Y. The role of family decision makers in festival tourism. Int. J. Hosp. Manag. 2010, 29, 308-318. [CrossRef]

59. Hill, C.M. Farmers' perspectives of conflict at the wildlife-agriculture boundary: Some lessons learned from African subsistence farmers. Hum. Dimens. Wildl. 2004, 9, 279-286. [CrossRef]

60. Curtin, S. Wildlife tourism: The intangible, psychological benefits of human-wildlife encounters. Curr. Issues Tour. 2009, 12, 451-474. [CrossRef]

61. Vaske, J.J.; Timmons, N.R.; Beaman, J.; Petchenik, J. Chronic wasting disease in Wisconsin: Hunter behavior, perceived risk, and agency trust. Hum. Dimens. Wildl. 2004, 9, 193-209. [CrossRef]

62. Gstaettner, A.M.; Rodger, K.; Lee, D. Visitor perspectives of risk management in a natural tourism setting: An application of the theory of planned behaviour. J. Outdoor Recreat. Tour. 2017, 19, 1-10. [CrossRef]

63. Lee, E. Performing colonisation: The manufacture of Black female bodies in tourism research. Ann. Tour. Res. 2017, 66, 95-104. [CrossRef]

64. Sonmez, S.F.; Graefe, A.R. Determining future travel behavior from past travel experience and perceptions of risk and safety. J. Travel Res. 1998, 37, 171-177. [CrossRef]

65. Karl, M. The influence of risk perception on destination choice processes. Eur. J. Tourism Res. 2018, 18, 160-163.

66. Monk, J.; Hanson, S. On not excluding half of the human in human geography. Prof. Geogr. 1982, 34, 11-23. [CrossRef]

67. Aman, J.; Abbas, J.; Mahmood, S.; Nurunnabi, M.; Bano, S. The influence of islamic religiosity on the perceived socio-cultural impact of sustainable tourism development in pakistan: A structural equation modeling approach. Sustainability 2019, 11, 3039. [CrossRef]

68. Ballantyne, R.; Hughes, K.; Lee, J.; Packer, J.; Sneddon, J. Visitors' values and environmental learning outcomes at wildlife attractions: Implications for interpretive practice. Tour. Manag. 2018, 64, 190-201. [CrossRef]

69. Cai, L.A.; Combrink, T.E. Japanese female travelers: A unique outbound market. Asia Pac. J. Tour. Res. 2000, 5, 16-24. [CrossRef]

70. D'Lima, C.; Everingham, Y.; Diedrich, A.; Mustika, P.L.; Hamann, M.; Marsh, H. Using multiple indicators to evaluate the sustainability of dolphin-based wildlife tourism in rural India. J. Sustain. Tour. 2018, 26, 1687-1707. [CrossRef]

71. Antoine, Z.; Miao, X. Research on wife's participation in tourism decision-making (translation). Hum. Geogr. $2003,18,66-69$. 